\title{
Shared Idiotopes and Restricted Immunoglobulin Variable Region Heavy Chain Genes Characterize Murine Autoantibodies of Various Specificities
}

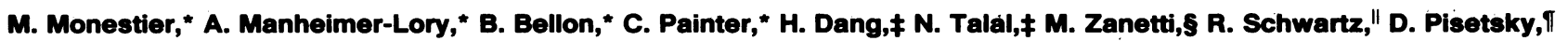 \\ R. Kuppers,"* N. Rose,"* J. Brochier,ł‡ L. Klareskog,\$§ R. Holmdahl,\$§ B. Erlanger, \\ *Department of Microbiology, Mount Sinai School of Medicine, New York 10029; †Department of Medicine, Division of Clinical \\ Immunology, University of Texas at San Antonio, San Antonio, Texas 78212; §Department of Immunology, Medical Biological Institute, \\ La Jolla, California 92037; "Department of Medicine, Tufts New England Medical Center, Boston, Massachusetts 02111; आMedical \\ Service, Durham Veterans Administration Hospital and Division of Rheumatology and Immunology, Duke University, Durham, North \\ Carolina 27706; ${ }^{* *}$ School of Hygiene and Public Health, The Johns Hopkins University, Baltimore, Marylaind 21218; $\ddagger \ddagger$ Hopital Saint- \\ Eloi, Montpellier, France; \$\$Department of Medical and Physiological Chemistry, Uppsala University, Sweden; and ${ }^{\prime \prime \prime}$ Department of \\ Biochemistry, College of Physicians and Surgeons of Columbia University, New York 10027
}

\begin{abstract}
The study of the Ig variable region heavy chain $\left(V_{H}\right)$ genes used to encode antibodies specific for self-epitopes from murine hybridomas showed that three $V_{H}$ families are primarily utilized: $V_{H} J 558$, the largest family, and $V_{H} Q P C 52$ and $V_{H} 7183$, the families most proximal to the Ig joining region heavy chain genes. These monoclonal autoantibodies express cross-reactive idiotopes shared by rheumatoid factors and antibodies specific for Sm. The expression of these idiotypes is independent of major histocompatibility complex and Ig constant region heavy chain haplotypes, self-antigen specificity, and even the $V_{H}$ gene family utilized.

Though the experiments described here are limited to murine autoantibodies, similarities exist between murine and human autoimmune diseases. Studies that aim to investigate the relationship between $V_{H}$ gene expression and the presence of crossreactive idiotypes among human autoantibodies should enable us to better understand the mechanisms of autoimmunity and self-tolerance.
\end{abstract}

\section{Introduction}

Autoantibodies of various specificities are not only features of many autoimmune diseases but also occur frequently in chronic infections, aged individuals, and after the use of numerous drugs (1). Thus, a predisposition to autoimmunity has been preserved throughout evolution, and the expression of autoimmunity is surprisingly common.

One striking feature of both human and murine autoantibodies is the incidence of idiotypic crossreactivity (IdX). ${ }^{1}$ This has been reported among antibodies to thyroglobulin $(2,3)$, DNA $(4,5,6), \mathrm{Sm}(7)$, and acetylcholine receptor (8), as well as with

Address correspondence to Dr. Monestier, Department of Microbiology, Mount Sinai School of Medicine, Annenberg Building 16-60, One Gustave Levy Place, New York, NY 10029.

Received for publication 15 January 1986.

1. Abbreviations used in this paper: Id, idiotype; IdX, idiotypic crossreactivity; LPS, lipopolysaccharide; MAb, monoclonal antibody; RF, rheumatoid factor; $\mathrm{V}_{\mathrm{H}}$, Ig variable region heavy chain gene.

J. Clin. Invest.

(c) The American Society for Clinical Investigation, Inc.

0021-9738/86/09/0753/07 \$1.00

Volume 78, September 1986, 753-759 rheumatoid factors $(9,10,10 \mathrm{a})$. In addition, there is a high degree of IdX among natural murine autoantibodies with multiple specificities (11).

In previous studies, we identified an IdX among murine monoclonal rheumatoid factors (RFs) originating from both normal and autoimmune strains. Moreover, we determined that these monoclonal antibodies (MAbs) are encoded by a limited set of Ig variable region heavy chain $\left(V_{H}\right)$ gene families.

In this communication we report the results of an extended study of a large panel of monoclonal autoantibodies of various specificities. Our analysis indicates that monoclonal autoantibodies of various specificities are encoded by $V_{H}$ genes from three families and that many of them share IdXs. The expression of this IdX is independent of major histocompatibility complex and Ig constant region heavy chain gene complexes as well as the $V_{H}$ gene utilized.

\section{Methods}

The origin, specificity, and isotypes of the monoclonal autoantibodies used in this study are shown in Table I.

As a control for idiotype (Id) specificity, 16 MAbs specific for influenza viruses (12 for PR8 and 4 for X31) were used. These antibodies are encoded by genes from the $V_{H} 7183$ family (19).

Identification of expressed $V_{H}$ gene families. Briefly, RNA from cytoplasmic lysates prepared from $10^{7}$ cells was fixed to nitrocellulose using a slot-blotting apparatus (20). The filters were baked, hybridized to $V_{H}$ gene probes, washed, and autoradiographed as described previously (21).

Preparation of $V_{H}$ gene probes. The $\mathrm{V}_{\mathrm{H}}$-specific fragments representative of the various $V_{\mathbf{H}}$ families were prepared as described previously (22).

Preparation of total RNA and Northern blot analysis. Total RNA was prepared from 3-5 $\times 10^{7}$ cells using the guanidinium thiocyanate extraction procedure. Northern blotting (used to confirm $V_{H}$ gene family assignments) was performed by electrophoretically fractionating the RNA on a $1.2 \%$ agarose gel ( $6 \%$ formaldehyde) in $40 \mathrm{mM}$ 4-morpholinepropanesulfonic acid, $20 \mathrm{mM} \mathrm{NaOAc}$, and $2 \mathrm{mM}$ EDTA. The gel was blotted without pretreatment onto nitrocellulose using $20 \times$ standard saline citrate (3 M NaCl, 0.3 M Na citrate) (22).

Study of idiotypy. The expression of IdX has been studied by competitive inhibition radioimmunoassay. Several polyclonal rabbit anti-Id antibodies were used; their preparation, purification, and specificity have been previously described $(3,23,10 a)$.

The following anti-Id antibodies were used: anti-LPS 10-1 Id, specific for a BALB/c RF; anti-129-48 Id, an anti-129/Sv RF MAb; anti-Y2 Id, an MRL/lpr anti-Sm MAb; anti-62 Id, a BALB/c antithyroglobulin MAb; and anti-PY102 Id, an anti-PR8 influenza virus-specific MAb.

Competitive inhibition radioimmunoassay was carried out as follows. Briefly, microtiter plates were coated overnight at $4^{\circ} \mathrm{C}$ with $10 \mu \mathrm{g} / \mathrm{ml}$ 
Table I. Origin, Specificity, and Isotypes of Autoantibodies

\begin{tabular}{|c|c|c|c|}
\hline Origin & Designation and isotypes & Specificity & Reference \\
\hline $\begin{array}{l}\text { 6-mo-old } 129 / \mathrm{Sv} \\
\text { "spontaneous" }\end{array}$ & $\begin{array}{l}129-48(\mu \kappa), 129-78(\mu \kappa), 129-74(\gamma 3 \kappa) \\
129-102(\mu \kappa), 129-66(\mu \kappa), 129-61(\mu \kappa) \\
129-76(\mu \kappa), 129-77(\mu \kappa)\end{array}$ & $\mathbf{R F}$ & $10 \mathrm{a}$ \\
\hline $\begin{array}{l}\text { 5-mo-old MRL/lpr } \\
\text { "spontaneous" }\end{array}$ & 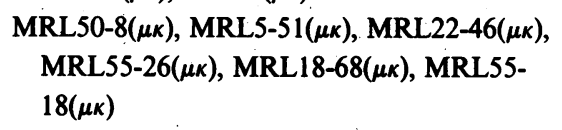 & $\mathbf{R F}$ & $10 \mathrm{a}$ \\
\hline $\begin{array}{l}\text { BALB/c } \\
\text { In vitro LPS-stimulated }\end{array}$ & 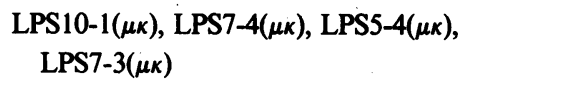 & RF & $10 \mathrm{a}$ \\
\hline $\begin{array}{l}\text { BALB/c } \\
\quad \text { Injected with } Y \text {. enterocolitica }\end{array}$ & $\mathrm{Y} 19-10(\mu \kappa), \mathrm{Y} 19-16(\mu \kappa), \mathrm{Y} 43-5(\mu \kappa)$ & RF & $10 \mathrm{a}$ \\
\hline MRL/lpr "spontaneous" & $\begin{array}{l}\mathrm{H} 102(\gamma 2 \mathrm{a} \kappa), \mathrm{H} 130(\mu \kappa), \mathrm{H} 241(\gamma 2 \mathrm{a} \kappa) \\
\quad \mathrm{RL} 1-3\end{array}$ & ss DNA & 12 \\
\hline BALB/c immunized & $\mathrm{HB} 2(\mu \kappa)$ & ds DNA & 13 \\
\hline BALB/c immunized & $\begin{array}{l}1-15(\gamma 1 \kappa), 62 \operatorname{Id}(\gamma 1 \kappa),{\mathrm{B} 10 \mathrm{H}_{2} \mathrm{~A}_{2}(\gamma 1 \kappa)}^{\text {APDB6}(\gamma 1 \kappa)}\end{array}$ & thyroglobulin & 3 \\
\hline CBA/J immunized & $\begin{array}{r}10 \mathrm{VA}_{2}(\mu \kappa), 10 \mathrm{IA}_{1}(\gamma 1 \kappa), 8.4 \mathrm{~A}_{3}(\mu \kappa) \\
8 . \mathrm{ID}_{2}(\gamma 2 \mathrm{~b} \kappa), 8 . \mathrm{IB}_{1}(\mu \kappa), 8.4 \mathrm{D}_{1}(\mu \kappa)\end{array}$ & thyroglobulin & 14 \\
\hline MRL/lpr "spontaneous" & $\mathrm{Y} 2(\gamma 2 \mathrm{a} \alpha), 2 \mathrm{G} 7(\gamma 2 \mathrm{a} x), \mathrm{Y} 12(\gamma 2 \mathrm{a} x), 6 \mathrm{~B} 6(\mu \mathrm{k})$ & $\mathrm{Sm}$ & 7 \\
\hline BALB/c immunized & F8D5 $(\mu \kappa)$ & AcR & \\
\hline BALB/c immunized & $\mathrm{LE} 4(\gamma 1 \kappa)$ & TSHR & 15 \\
\hline NZB "spontaneous" & $\mathrm{CP} 3(\mu \kappa), \mathrm{CP} 4(\mu \kappa)$ & Br-treated MRBC & 16 \\
\hline CBA "spontaneous" & $\mathrm{CP5}(\mu \kappa)$ & Br-treated MRBC & 16 \\
\hline DBA/l immunized & $\begin{array}{l}\mathrm{A} 12(\gamma 2 \mathrm{~b} \kappa), \mathrm{B} 11(\gamma 1 \kappa), \mathrm{E} 8(\gamma 1 \kappa), \mathrm{F} 9(\mu \kappa) \\
\mathrm{C} 2(\gamma 2 \mathrm{~b} \kappa), \mathrm{E} 5(\gamma 1 \kappa), \mathrm{F} 4(\gamma 2 \mathrm{a} \kappa), \mathrm{F} 10(\gamma 1 \kappa) \\
\mathrm{E} 7(\gamma 1 \kappa), \mathrm{C} 1(\gamma 2 \mathrm{a} \kappa), \mathrm{B} 1\end{array}$ & collagen type II & 17 \\
\hline BALB/c immunized & HB8 $(\gamma 1 \kappa), \mathrm{HB} 9(\mu \kappa)$ & microfibrils & 18 \\
\hline BALB/c immunized & $\mathrm{HB} 10(\mu \kappa), \mathrm{HB} 11(\mu \kappa), \mathrm{HB} 12(\mu \kappa)$ & skin antigens & 18 \\
\hline
\end{tabular}

AcR, acetylcholine receptor; Br-MRBC, bromelain-treated mouse red blood cells; ds, double stranded; ss, single stranded; TSHR, thyroid-stimulating hormone receptor.

chromatographically purified anti-Id antibodies. After washing and postcoating with phosphate-buffered saline/bovine serum albumin, the plates were incubated for $2 \mathrm{~h}$ at $25^{\circ}$ with various dilutions of MAbs $(5,50$, and $500 \mathrm{ng} /$ well). After extensive washings, plates were incubated for $2 \mathrm{~h}$ at $25^{\circ}$ with ${ }^{125}$ I-labeled Id ligand $(50,000 \mathrm{cpm})$, washed extensively, and radioactivity was counted in a gamma counter. Antibodies yielding at least $40 \%$ inhibition were considered IdX-positive.

\section{Results}

\section{Identification of $V_{H}$ gene families}

Since we previously determined that mouse monoclonal RFs obtained from various sources were encoded by only certain $V_{H}$ gene families, it was equally important to determine whether or not other types of autoantibodies also used a restricted set of $V_{H}$ genes.

Cytoplasmic lysates were prepared from $10^{7}$ hybridoma cells, transferred to nitrocellulose, and assayed by hybridization to a $V_{H}$ gene-specific probe for each known family (24). With some autoantibodies, the results obtained with the slot-blotting technique were unclear, and, in those cases, the purified RNA was hybridized to the $V_{H}$ probes using the Northern blotting technique.

Of the 43 autoantibodies that we tested, 17 used a $V_{H}$ gene from the largest family, $V_{H} J 558,5$ used a $V_{H}$ gene from $V_{H}$
QPC52, and 20 used a gene from $V_{H}$ 7183. Only one utilized a $V_{H}$ gene from the $V_{H} S 107$ family.

Examples of slot and Northern blotting are illustrated in Figs. 1 and 2. The results of this study, summarized in Table II, indicate that a restricted set of $\mathrm{V}_{\mathbf{H}}$ genes encodes murine monoclonal autoantibodies.

\section{Id of monoclonal autoantibodies}

Several idiotypic systems previously used to characterize IdX expressed on RF, anti-Sm, and antithyroglobulin autoantibodies were used in this study. All the autoantibodies used were chromatographically purified on a Sepharose 4B rat monoclonal antimurine kappa antibody column.

${ }^{125}$ I-Y19-10 anti-LPS10-1 Id antibodies. Y19-10 is a monoclonal RF induced in BALB/c mice by immunization with Yersinia enterocolitica. LPS10-1 is a monoclonal RF encoded by a $V_{H}$ gene from the $V_{H} 7183$ family. In this system, a large number of monoclonal autoantibodies with various specificities gave $>40 \%$ inhibition at a concentration of $10 \mu \mathrm{g} / \mathrm{ml}$. The results (Fig. 3) show that the inhibition was dose-dependent for the majority of the IdX-positive autoantibodies with the exception of 129-61, LPS7-4, MRL22-46, MRL50-8, 10VA 2 , and CP5, for which an inhibition was not observed with $5 \mathrm{ng}$ of antibody/ well.

${ }^{125}$ I-Y19-10 anti-129-48 Id antibodies. Monoclonal 129-48 


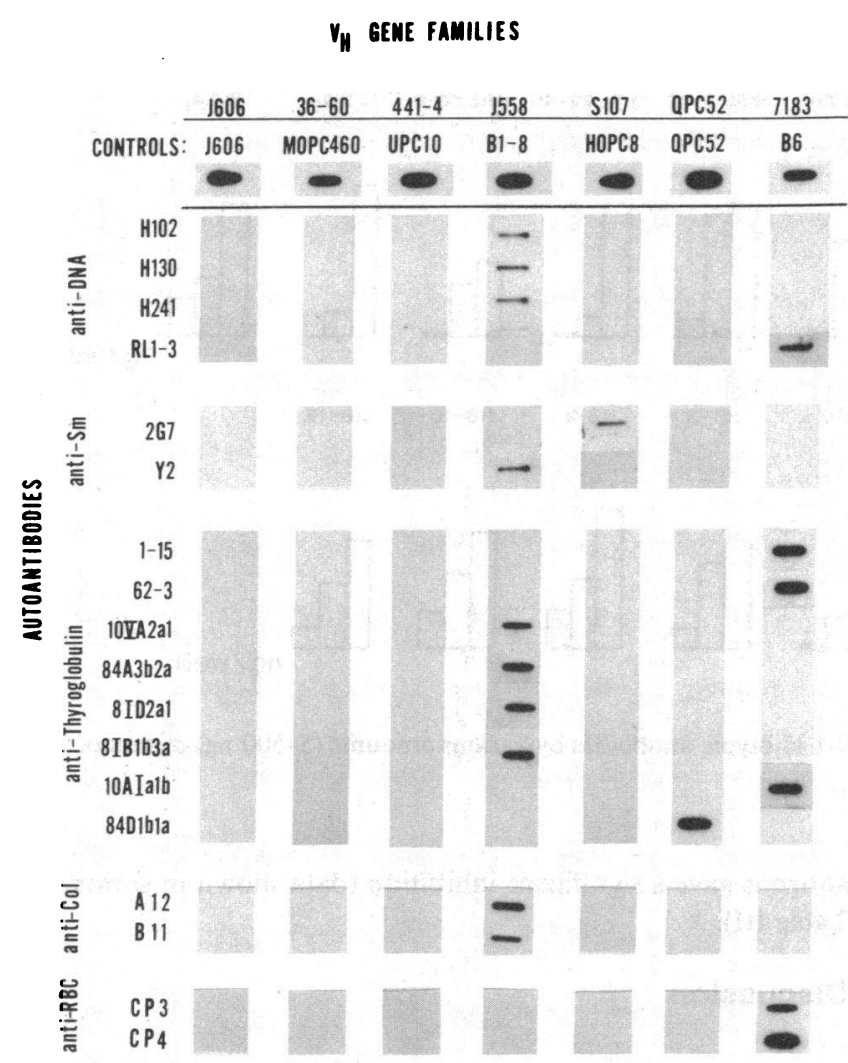

Figure 1. Utilization of $\mathrm{V}_{\mathrm{H}}$ genes by monoclonal autoantibodies. Autoradiogram composite of slot blot analysis of cytoplasmic RNA lysates from autoantibodies secreting hybridomas. Nitrocellulose was hybridized to ${ }^{32} \mathbf{P}$-nick translated $\mathbf{V}_{\mathbf{H}}$ gene probes under normal stringency conditions, washed, and autoradiographed. Positive control cell lines from each family are shown at the top of the figure.

is an RF obtained from $129 / \mathrm{Sv}$ mice, encoded by a $\dot{V}_{\mathbf{H}}$ gene closely related to the $V_{H} 37.1$ germline gene, a member of the $V_{H} 7183$ family (25).

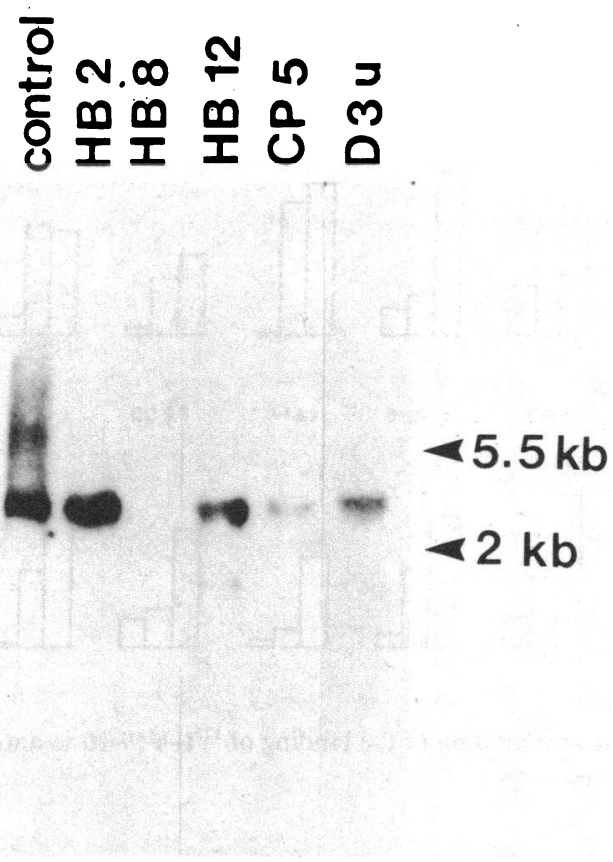

Figure 2. Northern blotting analysis of six hybridomas. $5 \mu \mathrm{g}$ RNA was electrophoresed through a $1.2 \%$ agarose gel (6\% formaldehyde), blotted, and hybridized to the ${ }^{32} \mathrm{P}$-nick translated $\mathrm{V}_{\mathrm{H}} 129-48$ probe.

In this system, an IdX was detected among four monoclonal RFs, two antithyroglobulin antibodies, one anti-collagen type II and two antiskin antigens (Fig. 4).

${ }^{125}$ I-Y2 anti-Y2 Id antibodies. Monoclonal Y2 is an Sm binding antibody obtained from MRL/lpr mice encoded by a $V_{H}$ gene from the $V_{H} J 558$ family.

IdX was observed in this system among three anti-Sm antibodies and eight RFs. For some antibodies (LPS10-4, Y43-5, Y19-16, MRL55-26, MRL55-18, and MRL18-68), a strong inhibition was only observed with $1 \mu \mathrm{g}$ of antibodies/well (Fig. 5).

Table II. Summary Results: Frequency of $V_{H}$ Gene Families Expressed in Autoantibodies

\begin{tabular}{|c|c|c|c|c|c|c|c|c|c|c|}
\hline \multirow[b]{2}{*}{$\mathbf{V}_{\mathbf{H}}$ family } & \multicolumn{9}{|l|}{ Specificity } & \multirow[b]{2}{*}{ Frequency } \\
\hline & $\mathbf{R F}$ & Thyroglobulin & DNA & Sm & Br-MRBC & TSHR & Collagen type II & Microfibrils & Skin antigens & \\
\hline$V_{H} \times 24$ & & & & & & & & & & $0 / 43$ \\
\hline$V_{H} J 606$ & & & & & & & & & & $0 / 43$ \\
\hline$V_{H} 36-60$ & & & & & & & & & & $0 / 43$ \\
\hline $\mathrm{V}_{\mathrm{H}} \mathrm{J} 558$ & MRL50-8 & $10 \mathrm{VA}_{2}$ & $\mathrm{H} 102$ & $\mathrm{Y} 12, \mathrm{Y} 2$ & & & $\mathrm{~A} 12, \mathrm{~B} 11, \mathrm{E} 8$ & & & $17 / 43$ \\
\hline & LPS5-4 & $8.4 \mathrm{~A}_{3}$ & H130 & 6B6 & & & & & & \\
\hline & Y19-10 & 8.ID & H241 & & & & & & & \\
\hline & Y19-16 & 8. $\mathrm{IB}_{1}$ & & & & & & & & \\
\hline $\mathrm{V}_{\mathrm{H}} \mathrm{S} 107$ & & & & $2 \mathrm{G7}$ & & & & & & $1 / 43$ \\
\hline $\mathrm{V}_{\mathrm{H}} \mathrm{QPC} 52$ & $\begin{array}{l}\text { MRL5-51 } \\
\text { LPS7-3 }\end{array}$ & $8.4 \mathrm{D}_{1}$ & & & & & B1 & HB8 & & $5 / 43$ \\
\hline$V_{H} 7183$ & $\begin{array}{l}\text { 129-48, 129-78, } \\
\text { MRL22-46, } \\
\text { LPS10-1, 129-74, } \\
129-70,129-78\end{array}$ & $\begin{array}{l}1-15,62 \mathrm{Id} \\
\mathrm{B} 10 \mathrm{H}_{2} \mathrm{~A}_{2} \\
10 \mathrm{AI}\end{array}$ & $\begin{array}{l}\text { RL1-3 } \\
\text { HB2 }\end{array}$ & & $\begin{array}{l}\text { CP3 } \\
\text { CP4 } \\
\text { CP5 }\end{array}$ & LE4 & $\mathrm{D} 3 \mu$ & & HB10 HB12 & $20 / 43$ \\
\hline
\end{tabular}

Br-MRBC, bromelain-treated mouse red blood cells; TSHR, thyroid-stimulating hormone receptor. 


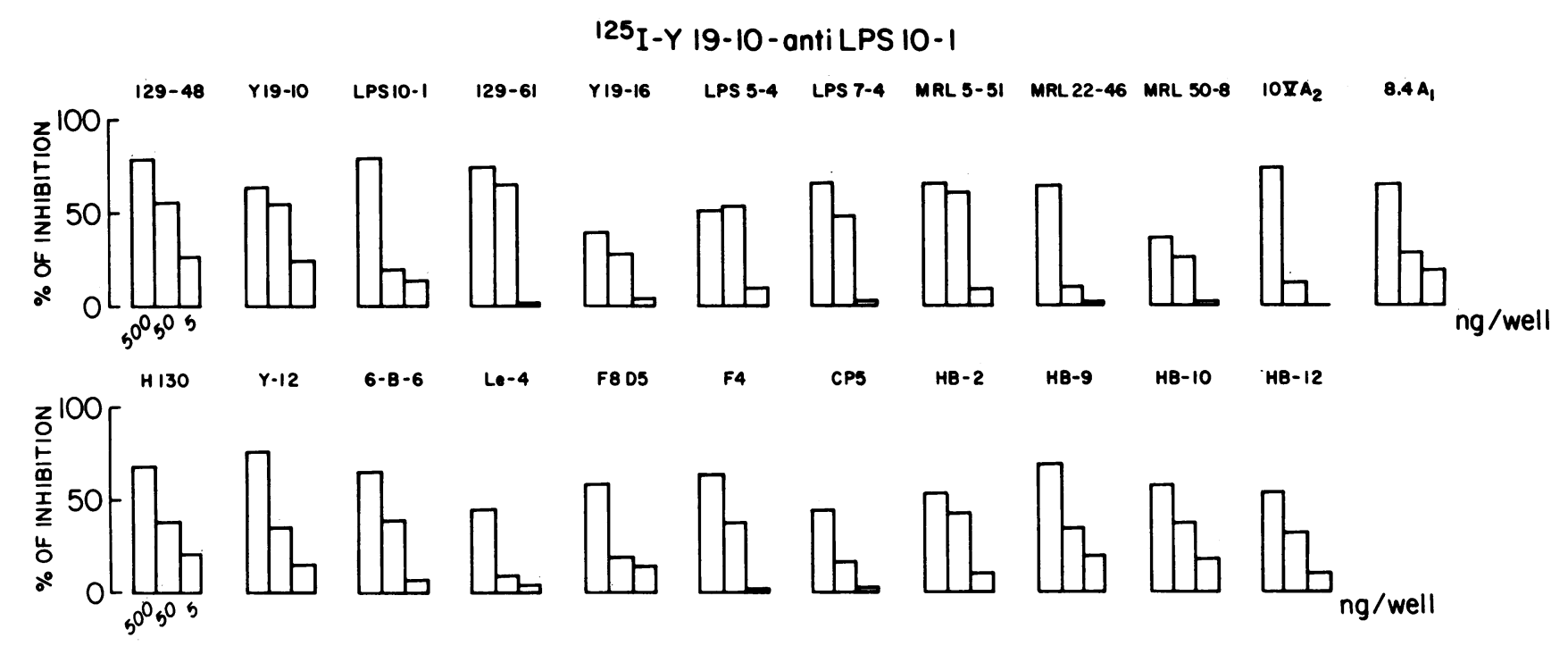

Figure 3. Competitive inhibition of the binding of ${ }^{125}$ I-Y19-10 to anti-LPS10-1 idiotypic antibodies by various amounts (5-500 ng) of monoclonal autoantibodies.

${ }^{125}$ I-1-15 anti-62 Id antibody. Monoclonal 1-15 and 62 Id were obtained from BALB/c mice that had been immunized with thyroglobulin. These antibodies are encoded by a $V_{H}$ gene from the $V_{H} 7183$ family. In this system, an IdX was observed on four monoclonal antithyroglobulin antibodies obtained from BALB/c mice but not on other antibodies with different specificities, with the exception of LPS10-1, which gave a weak inhibition (Fig. 6).

It was important to determine if our monoclonal autoantibodies also shared IdX with conventional antibodies specific for foreign antigens. For this purpose we studied the inhibitory activity of 16 antibodies specific for PR8 or X31 influenza viruses in our RF idiotypic systems. These antiviral antibodies were used as controls because they all use a $V_{H}$ gene from the 7183 family, which is highly represented (20/43) among the autoantibodies.

Only one (VM114) inhibited weakly (at $500 \mathrm{ng} /$ well) the binding of anti-129-48 Id to labeled Y19-10. The other antiinfluenza antibodies showed no inhibitory activity in any system used (data shown only in summary, Table III).

Conversely, we also studied the ability of monoclonal autoantibodies to inhibit an IdX system delineated among antiinfluenza antibodies. In these studies, we utilized labeled VM202 antibody and anti-Py102 Id antibodies. Both (VM202, Py102) are MAb-specific for PR8 influenza virus; they both use a $V_{H}$ gene from the 7183 family and a $V_{k} 21$ light chain (19).

None of our autoantibodies displayed any inhibitory activity in this system, whereas 6 of 16 MAbs specific for influenza virus antigens gave a significant inhibition (data shown in summary, Table III).

\section{Discussion}

In an attempt to define more precisely the genetic basis and molecular nature of autoantibodies, we studied the $V_{H}$ genes and the idiotypy of a panel of 61 monoclonal autoantibodies produced by hybridomas from several mouse strains. Some hybridomas were obtained from mice that spontaneously produce autoantibodies, including RFs obtained from old $129 / \mathrm{Sv}$ or MRL/lpr mice, anti-DNA and anti-Sm antibodies from MRL/ lpr mice, and anti-red blood cell antibodies from NZB or CBA mice. Others were obtained from normal immunized animals: e.g., RFs from BALB/c mice injected with $Y$. enterocolitica, antithyroglobulin antibodies from BALB/c or CBA/J mice injected with thyroglobulin, and antibodies against type II collagen from DBA/J mice.

Because our panel of MAbs covers various antigenic specificities, one might expect that all the $V_{H}$ gene families would be randomly used. However, we found that only a restricted number of $V_{H}$ gene families are used among these autoantibodies, namely J558 and the most $3^{\prime}$ families: QPC52 and 7183. This restriction is totally independent of combining site specificity and is not related to a spontaneous or induced origin.

It is interesting to note that among these three families the $3^{\prime} V_{H} 7183$ gene family is infrequently used by mature B cells, whereas it is frequently used normally in early development (22,

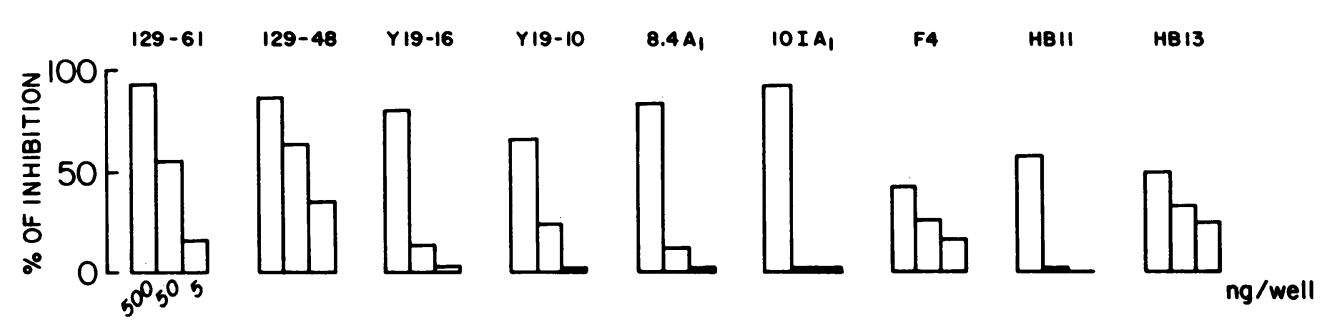

Figure 4. Competitive inhibition of the binding of ${ }^{125} \mathrm{I}-\mathrm{Y} 19-10$ to anti-129-48 idiotypic antibodies by various amounts $(5-500 \mathrm{ng})$ of monoclonal autoantibodies. 


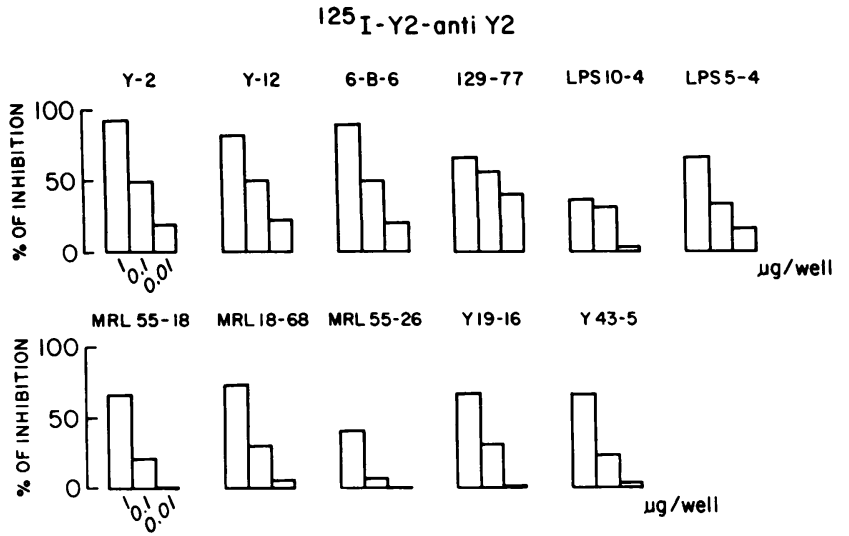

Figure 5. Competitive inhibition of the binding of ${ }^{125} \mathrm{I}-\mathrm{Y} 2$ anti-Y2 idiotypic antibodies by various amounts $(0.01-1 \mu \mathrm{g})$ of monoclonal autoantibodies.

26). Thus, it is possible that these $V_{H}$ genes used by autoantibodies reflect an immature repertoire of $B$ or pre-B cells. Alternatively, these $V_{H}$ genes may be representative of a subset of the $B$ cell lineage such as Ly-1 B cells, which secrete a high percentage of IgM autoantibodies (27). This lineage is highly represented in autoimmune strains such as $\mathrm{NZB}$ or $\left(\mathrm{NZB} \times \mathrm{NZW} \mathrm{F}_{1}\right.$ mice (28). Moreover, the $\mathrm{T} 1+\mathrm{B}$ cell subset, a human equivalent of

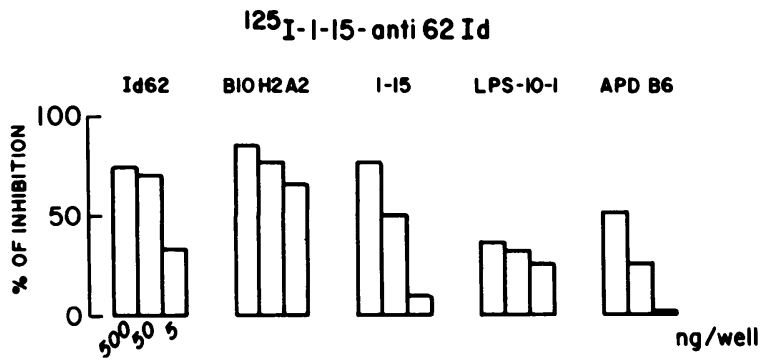

Figure 6. Competitive inhibition of the binding of ${ }^{125} \mathrm{I}-1-15$ to anti-62 idiotypic antibodies by various amounts (5-500 ng) of monoclonal autoantibodies.

the murine Ly-1 B subset, is significantly increased in patients with rheumatoid arthritis (29).

The autoantibodies studied in this report express IdX despite the fact that they are heterogeneous with respect to combining site and that they utilize different $\mathrm{V}_{\mathrm{H}}$ genes.

For example, among our large panel we have identified the presence of IdX originally borne by LPS10-1 and 129-48 RFs and by $\mathrm{Y} 2$, a monoclonal anti-Sm antibody. The presence of these IdXs is independent of their specificity, major histocompatibility complex, and Ig constant region heavy chain gene complexes.

Table III. Summary Results: Fraction of Autoantibodies Expressing Crossreactive Idiotypes

\begin{tabular}{|c|c|c|c|c|c|c|c|c|c|c|c|}
\hline \multirow[b]{2}{*}{$\begin{array}{l}\text { Anti-Id } \\
\text { antibodies }\end{array}$} & \multicolumn{11}{|l|}{ Specificity } \\
\hline & $\mathbf{R F}$ & $\begin{array}{l}\text { Thyro- } \\
\text { globulin }\end{array}$ & DNA & Sm & Br-MRBC & TSHR & $\begin{array}{l}\text { Collagen } \\
\text { type II }\end{array}$ & AcR & $\begin{array}{l}\text { Micro- } \\
\text { fibrils }\end{array}$ & $\begin{array}{l}\text { Cytoplasmic } \\
\text { skin antigens }\end{array}$ & $\begin{array}{l}\text { Influenza } \\
\text { virus }\end{array}$ \\
\hline \multirow{3}{*}{$\begin{array}{l}\text { Y19-10 anti- } \\
\text { LPS10-1-Id }\end{array}$} & 129-48, Y19-10, & $10 \mathrm{VA}_{2}$ & H130 & Y12 & CP5 & LE4 & F4 & F8D5 & HB9 & HB10 & \\
\hline & $\begin{array}{l}\text { LPS10-1, 129-61, } \\
\text { Y19-16, LPS5-4, } \\
\text { LPS7-4, MRL5-51, } \\
\text { MRL22-46, MRL50-8 }\end{array}$ & 8.4. $A_{1}$ & HB2 & 6B6 & & & & & & HB12 & \\
\hline & $10 / 20^{*}$ & $2 / 9$ & $2 / 5$ & $2 / 4$ & $1 / 3$ & $1 / 1$ & $1 / 10$ & $1 / 1$ & $1 / 2$ & $2 / 3$ & $0 / 16$ \\
\hline \multirow{5}{*}{$\begin{array}{l}\text { Y19-10 anti- } \\
129-48 \text { Id }\end{array}$} & $129-48$ & $8.4 A_{1}$ & & & & & F4 & & & HB10 & VM114 \\
\hline & Y19-10 & $10 \mathrm{IA}_{1}$ & & & & & & & & HB11 & \\
\hline & $129-61$ & & & & & & & & & & \\
\hline & Y19-16 & & & & & & & & & & \\
\hline & $4 / 20$ & $2 / 9$ & $0 / 5$ & $0 / 4$ & $0 / 3$ & $0 / 1$ & $1 / 10$ & $0 / 1$ & $0 / 2$ & $2 / 3$ & $1 / 16$ \\
\hline \multirow{5}{*}{$\begin{array}{l}\text { Y2 anti-Y2 } \\
\text { Id }\end{array}$} & 129-77, LPS5-4, & & & Y2 & & & & & & & \\
\hline & MRL55-18, LPS10-4, & & & Y12 & & & & & & & \\
\hline & MRL16-68, MRL55-26, & & & 6B6 & & & & & & & \\
\hline & Y19-10, Y43-5 & & & & & & & & $\mathrm{ND} \ddagger$ & ND & ND \\
\hline & $8 / 20$ & $0 / 9$ & $0 / 5$ & $3 / 4$ & $0 / 3$ & $0 / 1$ & $0 / 10$ & $0 / 1$ & & & \\
\hline \multirow{5}{*}{$\begin{array}{l}1-15 \text { anti-62 } \\
\text { Id }\end{array}$} & LPS10-1 & $1-15$ & & & & & & & & & \\
\hline & & ADPB6 & & & & & & & & & \\
\hline & & 62ID & & & & & & & & & \\
\hline & & $\mathrm{B} 10 \mathrm{H}_{2} \mathrm{~A}_{2}$ & & & & & & & & & ND \\
\hline & $1 / 20$ & $4 / 9$ & $0 / 5$ & $0 / 4$ & $0 / 3$ & $0 / 1$ & $0 / 10$ & $0 / 1$ & $0 / 2$ & $0 / 3$ & \\
\hline $\begin{array}{l}\text { VM202 anti- } \\
\text { PY102 Id }\end{array}$ & $0 / 20$ & $0 / 9$ & $0 / 5$ & $0 / 4$ & $0 / 3$ & $0 / 1$ & $0 / 10$ & $0 / 1$ & ND & ND & $6 / 16$ \\
\hline
\end{tabular}

AcR, acetylcholine receptor; Br-MRBC, bromelain-treated mouse red blood cells; TSHR, thyroid-stimulating hormone receptor. ${ }^{*}$ Fraction of antibodies expressing cross-reactive idiotypes. $¥$ Not done. 
At first glance, the presence of an IdX on antibodies encoded by various $V_{H}$ gene families is surprising, since it is accepted that IdX are often markers of a particular $V_{H}$ family, as was shown for antidextran, antinitrophenyl, or antiarsonate antibodies (30).

However, several exceptions to this rule have been reported. For example, antiarsonate antibodies produced by BALB/c mice express IdX despite the fact that they use a $V_{H}$ gene that does not derive from the $V_{H}$ 36-65 germline gene (31). In addition, crossreactive Ids were also observed for antibodies of various specificities that were derived from different members of the same family of $V_{H}$ germline genes (32). Furthermore, our previous molecular data showed that shared IdX can result even if $\mathrm{D}$ and $\mathrm{JH}$ segments are not identical. It is possible that this kind of IdX is related to a short DNA segment conserved among $V_{H}$ gene families used by antibodies. In fact, we and others suggest that a conserved framework may be responsible for IdX (10a).

These IdXs shared by autoantibodies of various specificities may be a clue to the genetic and immunoregulatory basis of autoimmunity. It is clear that the cells that produce these autoantibodies are present in normal animals, where they can be induced at times into clonal expansion by hyperimmunization, as in the case of RF. They may also emerge spontaneously during the course of an autoimmune disease, or perhaps even during the aging process.

The precise mechanisms that down-regulate these potentially autoreactive B cell clones are not known, but they probably involve both intracellular (i.e., genetic) and extracellular (i.e., suppression) events. One such intracellular event, based on the findings in this report, would be the utilization of a restricted set of $V_{H}$ genes. The presence of an unusual $B$ cell subset (e.g., Ly-1 B cells) may be associated or even necessary for this to occur.

Extracellular mechanisms leading to polyclonal B cell activation and autoimmunity may involve failure of $T$ cell suppression, interference with network regulation based on Id recognition, failure of natural killing $(33,34,35)$, or some combination of these. If IdX is present on the surface of autoreactive B cells and is recognized by other cells, then its overabundance in autoimmunity may contribute in some way to immunoregulatory failure and disease pathogenesis.

\section{Acknowledgments}

We are grateful to Dr. Bussard for the gift of monoclonal antibodies CP3, CP4, and CP5.

This investigation was supported by United States Public Health Service grant No. A118316-04 from the National Institute of Aging, National Institutes of Health. Dr. Monestier is supported by the French Government and the Foundation pour la Recherche Medicale (Paris).

\section{References}

1. N. Talal, editor. 1977. Autoimmunity: Genetic, Immunologic, Virologic and Clinical Aspects. Academic Press, New York.

2. McCoy, J. P., J. H. Michaelson, and P. E. Bigazzi. 1983. Antiidiotypic immunity and autoimmunity III. Investigations in human autoimmune thyroiditis. Life Sci. 32:109-118.

3. Zanetti, M., M. De Baets, and J. Rogers. 1983. High degree of idiotypic cross-reactivity among murine monoclonal antibodies to thyroglobulins. J. Immunol. 131:2452-2457.

4. Schwartz, R. S., and D. Stollar. 1985. Origins of anti-DNA autoantibodies. J. Clin. Invest. 75:321-327.
5. Halpern, R., A. Davidson, A. Lazo, G. Solomon, R. Lahita, and B. Diamond. 1985. Familial systemic lupus erythematosus. Presence of a cross-reactive idiotype in healthy family members. J. Clin. Invest. 76: 731-736.

6. Hahn, B. H., and F. M. Ebling. 1984. A public idiotypic determinant is present on spontaneous cationic IgG antibodies to DNA from mice of unrelated lupus prone strains. J. Immunol. 133:3015-3019.

7. Pisetsky, D. S., and E. A. Lerner. 1982. Idiotypic analysis of a monoclonal anti-Sm antibody. J. Immunol. 129:1489-1491.

8. Dwyer, D. S., R. J. Bradley, C. K. Urquhart, and J. F. Kearney. 1983. Naturally occurring anti-idiotypic antibodies in myasthenia gravis patients. Nature (Lond.). 301:611-614.

9. Andrews, D. W., and J. D. Capra. 1981. Complete amino acid sequence of variable domains from two monoclonal human anti-gammaglobulins of the Wa crossidiotypic group: suggestion that the J segments are involved in the structural correlate of the idiotype. Proc. Natl. Acad. Sci. USA. 78:3799-3803.

10. Chen, P. P., S. Fong, D. Normansell, R. A. Houghten, J. G. Karras, J. H. Vaughan, and D. A. Carson. 1984. Delineation of a crossreactive idiotype on human autoantibodies with antibody against a synthetic peptide. J. Exp. Med. 159:1502-1511.

10a. Manheimer-Lory, A., M. Monestier, B. Bellon, F. Alt, and C. Bona. 1986. Fine specificity, idiotypy, and nature of cloned $V_{H}$ genes of murine monoclonal rheumatoid factor antibodies. Proc. Natl. Acad. Sci. USA. In press.

11. Lymberi, P., G. Dighiero, T. Ternynck, and S. Avrameas. 1985. A high incidence of cross-reactive idiotypes among murine natural autoantibodies. Eur. J. Immunol. 15:702-707.

12. Rauch, J., E. Murphy, J. B. Roths, B. D. Stollar, and R. S. Schwartz. 1982. A high frequency idiotypic marker of anti-DNA autoantibodies in MRL/lpr mice. J. Immunol. 129:236-241.

13. Monier, J. C., J. Brochier, A. Moreira, C. Sault, and B. Roux. 1984. Generation of hybridoma antibodies to double-stranded DNA from non-autoimmune BALB/c strain: studies on anti-idiotype. Immunol. Lett. 8:61-68.

14. Rose, N. R., M. A. Accavitti, and M. A. Leon. 1985. Thyroglobulin-specific monoclonal antibodies. In Antibodies: Protective, Destructive and Regulatory Role. F. Milgrom, C. J. Abeyounis, and B. Albini, editors. Karger, Basel, Switzerland. 171-178.

15. Cleveland, W. L., N. H. Wasserman, P. Sarangurajan, A. S. Penn, and B. F. Erlanger. 1983. Monoclonal antibodies to the acetylcholine receptor by a normally functioning autoantiidiotypic mechanism. Nature (Lond.). 305:56-57.

16. Poncet, P., H. P. Kocher, J. Pages, J. C. Jatou, and A. E. Bussard. 1985. Monoclonal antibodies against mouse red blood cells: a family of structurally restricted molecules. Mol. Immunol. 22:541-551.

17. Holmdahl, R., K. Rubin, L. Klareskog, E. Larsson, and H. Wigzell. 1986. Characterization of the antibody response in mice with type II collagen-induced arthritis, using monoclonal anti-type II collagen antibodies. Arthritis Rheum. 29:400-410.

18. Dawson, J. F., J. Brochier, D. Schmitt, S. Saeland, and J. Thivolet. 1984. Elastic fibers: histological correlation with orcein and a new monoclonal antibody, HB8. Br. J. Dermatol. 110:539-546.

19. Moran, T. M., M. A. Reale, M. Monestier, R. Mayer, J. L. Schulman, and C. A. Bona. 1986. Idiotypy of anti-influenza virus immune response. Concept. Immunopathol. 3:233-252.

20. White, B. A., and F. C. Bancroft. 1982. Cytoplasmic dot hybridization. Simple analysis of relative mRNA levels in multiple small cell or tissue samples. J. Biol. Chem. 257:8569-8572.

21. Alt, F. W., N. Rosenberg, V. Enea, E. Siden, and D. Baltimore. 1982. Multiple immunoglobulin heavy chain gene transcripts in Abelson murine leukemia virus transformed cell lines. Mol. Cell. Biol. 2:386400.

22. Yancopoulos, G. D., S. V. Desiderio, M. Paskind, D. Kearny, D. Baltimore, and F. W. Alt. 1984. Preferential utilization of the most $J_{H}$ proximal $V_{H}$ gene segments in pre B cell lines. Nature (Lond.). 311: 727-733.

23. Dang, H., M. Fischback, and N. Talal. 1985. Anti-idiotypic an- 
tiserum to monoclonal anti-Sm inhibits the autoantigen-induced proliferative response. J. Immunol. 134:3825-3830.

24. Brodeur, P., and R. Riblet. 1984. The immunoglobulin heavy chain variable region (Igh-V) locus in the mouse I. $100 \mathrm{Igh}-\mathrm{V}$ genes comprise 7 families of homologous genes. Eur. J. Immunol. 14:922930.

25. Hartman, A. B., and S. Rudikoff. 1984. $V_{H}$ genes encoding the immune response to $\beta(1-6)$ galactan: somatic mutation in the IgM molecules. EMBO (Eur. Mol. Biol. Organ.) J. 3:3023-3030.

26. Perlmutter, R. M., J. F. Kearney, S. P. Chang, and L. E. Hood. 1985. Developmentally controlled expression of Immunoglobulin $V_{H}$ genes. Science (Wash. DC). 227:1597-1600.

27. Hayakawa, K., R. R. Hardy, M. Honda, L. A. Herzenberg, A. D. Steinberg, and L. A. Herzenberg. 1984. Ly1 B cells: functionally distinct lymphocytes that secrete IgM autoantibodies. Proc. Natl. Acad. Sci. USA. 81:2494-2498.

28. Hayakawa, K., R. R. Hardy, D. R. Parks, and L. A. Herzenberg. 1983. The Lyl B cell subpopulation in normal, immunodefective and autoimmune mice. J. Exp. Med. 157:202-218.

29. Plater-Zyberk, C., R. N. Maini, K. Lam, T. D. Kennedy, and G. Janossy. 1985. A rheumatoid arthritis B cell subset expresses a phenotype similar to that in chronic lymphocyte leukemia. Arthritis Rheum. 28: 971-976.

30. M. I. Green and A. Nisonoff, editors. 1984. The biology of idiotypes. Plenum Publishing Corp., New York. 19-59.

31. Leo, O., M. Slaoui, J. Marvel, E. C. B. Milner, J. Hiernaux, J. Moser, J. D. Capra, and J. Urbain. 1985. Idiotypic analysis of polyclonal and monoclonal anti-p-Azophenylarsonate antibodies of BABL/c mice expressing the major cross-reactive idiotype of the A/J strain. J. Immunol. 134:1734-1740.

32. Victor-Kobrin, C., T. Manser, T. M. Moran, T. Imanishi-Kari, M. Gefter, and C. A. Bona. 1985. Shared idiotopes among antibodies encoded by heavy chain variable region $\left(\mathrm{V}_{\mathrm{H}}\right)$ gene members of the J558 $\mathrm{V}_{\mathbf{H}}$ family as basis for cross-reactive regulation of clones with different antigen specificity. Proc. Natl. Acad. Sci. USA. 82:7696-7700.

33. Shoenfeld, Y., and R. S. Schwartz. 1984. Immunologic and genetic factors in autoimmune diseases. N. Engl. J. Med. 31:1019-1029.

34. Talal, N. 1978. Autoimmunity and the immunologic network. Arthritis Rheum. 21:853-861.

35. Talal, N. 1984. Interferon and natural killer cells in rheumatic diseases. In Immunology of Rheumatic Disease. S. Gupta and N. Talal, editors. Plenum Publishing Corp., New York. 141-163. 